\title{
PENGHALANG KEWARISAN DALAM PASAL 173 HURUF (a) KOMPILASI HUKUM ISLAM
}

\author{
Oleh: \\ Ahda Fithriani \\ Fakultas Syariah dan Ekonomi Islam IAIN Antasari, \\ Jl. Jenderal Ahmad Yani Km 4,5 Banjarmasin \\ Email: ahda_fithriani@yahoo.co.id
}

\begin{abstract}
The presence of Article 173 (a) Compilation of Islamic Law brought changes in Indonesia because Islamic inheritance particularly attempted murder and persecution to enter weight as a barrier inheritance. Previously, jurists agreed only three things that make an unobstructed heir to inherit that slavery, religious differences, and murder. Through the viewpoint of Islamic law, attempted murder and persecution weight of a renewal in Islamic law which is supported by one of the methods of ijtihad is sadd al-zari'at. Methods sadd al-zari'at closed the road for someone to expedite the distribution of the estate with attempted murder and severe persecution against muwarris. Through this method, the inheritance rights of the offender will be hindered because of his actions.
\end{abstract}

\begin{abstract}
Abstrak: Kehadiran pasal 173 huruf a Kompilasi Hukum Islam membawa perubahan dalam kewarisan Islam khususnya Indonesia karena memasukkan percobaan pembunuhan dan penganiyaan berat sebagai penghalang kewarisan. Sebelumnya, fuqaha hanya menyepakati tiga hal yang menjadikan seorang ahli waris terhalang untuk mendapatkan warisan yaitu perbudakan, perbedaan agama, dan pembunuhan. Melalui sudut pandang hukum Islam, percobaan pembunuhan dan penganiyaan berat merupakan pembaharuan dalam hukum Islam yang didukung oleh salah satu metode ijtihad yaitu sadd al-zari'at. Metode sadd alzari'at menutup jalan bagi seseorang untuk mempercepat pembagian harta warisan dengan melakukan percobaan pembunuhan dan penganiyaan berat terhadap muwarrisnya. Melalui metode ini maka hak waris pelaku akan terhalang karena perbuatannya tersebut.
\end{abstract}

Kata Kunci: Penghalang, kewarisan, percobaan, pembunuban, penganiyaan

\section{Pendahuluan}

Al Qur'an sebagai kitab suci umat Islam memuat petunjuk-petunjuk untuk kehidupan dunia dan akhirat yang sebagian besar dijelaskan secara global. Di dalamnya terdapat hukum-hukum yang menjadi landasan umat Islam. Namun, diantara berbagai permasalahan hukum yang dijelaskan dalam $\mathrm{Al}$ quran, terdapat satu permasalahan hukum yaitu mengenai aturan pembagian harta warisan yang diuraikan secara terperinci.

Kata "warits" dari 'yaritsu-irtsan-wamiratsan' terdapat dalam Al Quran surah An-Naml: 16 "Dan Sulaiman telah mewarisi Daud .... ${ }^{1}$

Arti "mirats" menurut bahasa adalah berpindahnya sesuatu dari seseorang kepada orang lain atau dari suatu kaum kepada kaum lainnya. Mengutip definisi yang diberikan Wirjono

Departemen Agama RI, AL-Qur'an dan Terjemahnya, (Jakarta: CV. Naladana, 2004)
Prodjodikoro, waris adalah berbagai aturan tentang perpindahan hak milik seseorang yang telah meninggal dunia kepada ahli warisnya. ${ }^{2}$ Dalam istilah lain, waris disebut juga dengan faraidh yang artinya bagian tertentu yang dibagi menurut agama Islam kepada semua yang berhak menerimanya. ${ }^{3}$ Kata al-faraidh ini dalam bahasa Arab menunjukkan jama' dari mufradnya al-faridhah yang bermakna almafrudhah atau sesuatu yang diwajibkan. Artinya, pembagian yang telah ditentukan kadarnya. ${ }^{4}$

Dari beberapa definisi waris di atas, dapat disimpulkan bahwa ilmu waris atau ilmu faraidh

\footnotetext{
2 Wirjono Prodjodikoro, Hukum Waris Indonesia, (Bandung: Sumur Bandung, 1991) hal 13

3 Mohammad Rifa'i, Kifayatul Akbyar, (Semarang: Toha Putra, 1978), hal 242

${ }^{4}$ Wahidah, Al-Mafqud: Kajian Tentang Kewarisan Orang Hilang, (Banjarmasin: Antasari Press, 2008), hal 2
} 
adalah pengetahuan yang membahas seluk beluk pembagian harta waris, ketentuan ahli waris, dan bagian-bagiannya.

Ketentuan dari waris mewarisi ini adalah manifestasi dari pengakuan adanya hak milik perorangan, baik terhadap harta bergerak maupun tidak bergerak karena secara otomatis hukum waris mengakui adanya perpindahan hak dan kepemilikan si pewaris kepada ahli warisnya, ketika terjadi peristiwa kematian. ${ }^{5}$

Penyelesaian hak-hak dan kewajiban sebagai akibat dari adanya peristiwa hukum kematian maka harta peninggalan seseorang akan diatur oleh hukum kewarisan. Oleh karena itu, perlu pengaturan kewarisan menetapkan secara rinci agar tidak ada perselisihan antara sesama ahli waris sepeninggal orang yang hartanya diwarisi. ${ }^{6}$

Syariat Islam telah menetapkan aturan waris dengan bentuk yang sangat teratur dan adil. Di dalamnya ditetapkan perpindahan hak dan kepemilikan harta bagi semua warisnya, baik laki-laki maupun perempuan, besar ataupun kecil, sedikit ataukah banyak harta yang ditinggalkan kerabat (pewarisnya), sebagaimana disebutkan dalam firman-Nya:

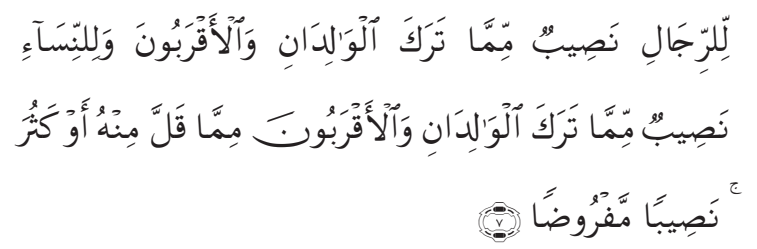

\begin{abstract}
"Bagi orang laki-laki ada hak bagian dari harta peninggalan ibu-bapa dan kerabatnya, dan bagi orang wanita ada hak bagian (pula) dari harta peninggalan ibu-bapa dan kerabatnya, baik sedikit atau banyak menurut bahagian yang telah ditetapkan."
\end{abstract}

Selain itu, terdapat ayat-ayat lain yang berkaitan dengan masalah kewarisan baik secara langsung maupun tidak langsung di dalam Al Qur'an, diantaranya:

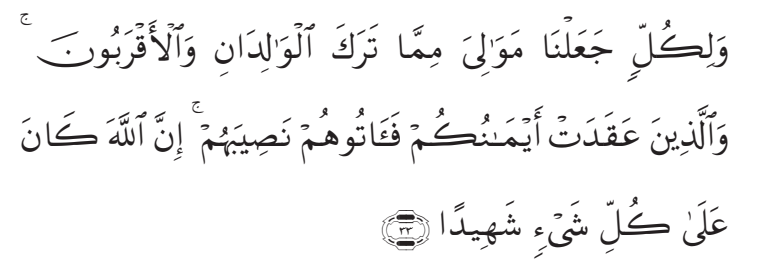

\footnotetext{
${ }^{5}$ Ibid

${ }^{6}$ Mohd. Idris Ramulyo, Hukum Kewarisan, Hukum Perkawinan, Hukum Acara Peradilan Agama dan Zakat Menurut Hukum Islam, (Jakarta: Sinar Grafika, 1990), hal 993
}

"Bagi tiap-tiap harta peninggalan dari harta yang ditinggalkan ibu bapak dan karib kerabat, kami jadikan pewaris-pewarisnya dan (jika ada) orang-orang yang kamu telah bersumpah setia dengan mereka, maka berilah kepada mereka bahagiannya. Sesungguhnya Allah menyaksikan segala sesuatu.

Asas terpenting dalam ilmu waris adalah asas 'adalah yakni prinsip keadilan. Ciri keadilan Allah adalah tidak melalaikan dan mengabaikan hak setiap ahli waris. Bahkan dengan aturan yang sangat jelas dan sempurna, Allah menentukan pembagian hak setiap ahli waris dengan adil dan penuh kebijaksanaan. Allah menetapkan hal itu dengan tujuan mewujudkan keadilan dalam kehidupan manusia, meniadakan kezaliman lakilaki atas perempuan, menutup rapat-rapat ruang gerak para pelaku kezaliman dan membangkitkan semangat persamaan derajat untuk semua manusia yang hidup di muka bumi.

Untuk memperoleh harta warisan tersebut, harus ada sebab-sebab seseorang berhak menerima warisan yaitu adanya pertalian nasab baik bersifat lurus ke bawah, ke atas, ataupun menyamping. Selain itu, hubungan perkawinan juga menjadi sebab seseorang menerima warisan.

Namun, seorang ahli waris tidak akan memperoleh harta warisan apabila dalam dirinya terdapat hal-hal yang menjadi penghalang dalam menerima harta warisan. Dalam faraidh, penghalang tersebut dinamakan dengan mawani' al-irtsi. Kata mawani' adalah bentuk jamak dari mani' yang menurut etimologi berarti pengahalang di antara dua hal dan terminology berarti sesuatu yang mengharuskan ketiadaan sesuatu yang lain.

Orang yang terhalang mewarisi disebut dengan mamnu' atau mahrum. Istilah tersebut harus dibedakan dengan istilah mahjub yang juga mempunyai arti sama dengan mamnu' atau mabrum. Perbedaan keduanya terletak pada kemutlakan tidak memperoleh harta warisan. Mabjub adalah ahli waris yang terhalang mendapat warisan karena adanya ahli waris lain yang lebih dekat kekerabatannya dengan pewaris. Ahli waris yang mabjub sifatnya hanya sementara karena apabila ahli waris yang menghalanginya sudah tidak ada maka ia akan tampil sebagai ahli waris. Adapun mamnu' atau mahrum adalah ahli waris yang terhalang karena kedudukannya yang diharamkan oleh Islam dan ini berlaku selamanya.

Beni Ahmad Saebani, Fikih Mawaris, (Bandung: Pustaka Setia, 2000), hal 75. 
Penghalang warisan (mamnu'/mahrum) mengakibatkan gugurnya hak ahli waris untuk menerima harta warisan dari harta peninggalan pewaris walaupun jarak kekerabatannya dengan si pewaris sangat dekat seperti anak yang membunuh orang tuanya atau anak yang berbeda agama dengan orang tuanya yang meninggalkan harta warisan tersebut.

Para ulama mazhab sepakat bahwa ada tiga hal yang menghalangi warisan yaitu perbudakan, perbedaan agama, dan pembunuhan. Para faradbiyun telah bulat pendapatnya untuk menetapkan perbudakan itu adalah suatu hal yang menjadi pengahalang waris mewarisi berdasarkan adanya petunjuk umum dari suatu nash yang sharih yang menafikan kecakapan bertindak seorang budak dalam segala bidang yang termaktub dalam firman Allah surah An-Nahl: 75 berikut:

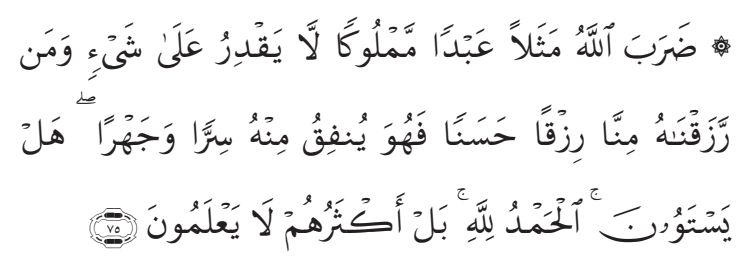

Allah membuat perumpamaan dengan seorang hamba sahaya yang dimiliki yang tidak dapat bertindak terhadap sesuatupun dan seorang yang kami beri rezki yang baik dari kami, lalu dia menafkahkan sebagian dari rezki itu secara sembunyi dan secara terang-terangan, Adakah mereka itu sama? segala puji hanya bagi Allah, tetapi kebanyakan mereka tiada mengetahui.

Berkaitan dengan adanya perbedaan agama, para ulama mazhab sepakat bahwa non muslim tidak bisa mewarisi muslim. Walaupun masih terdapat perbedaan pendapat terkait apakah seorang muslim bisa mewarisi non muslim.

Halangan mewarisi yang ketiga adalah pembunuhan terhadap pewaris. Sangat beralasan jika seseorang pembunuh tidak berhak atas harta yang ditinggalkan oleh orang yang dibunuhnya. Ahli waris ini ingin mempercepat memperoleh harta warisan dengan cara yang sangat tidak dibenarkan oleh hukum manapun baik hukum agama maupun hukum yang dibuat oleh manusia. Jumhur ulama telah sepakat untuk menetapkan bahwa pembunuhan itu pada prinsipnya menjadi penghalang mempusakai bagi si pembunuh terhadap harta peninggalan orang yang telah dibunuhnya. ${ }^{8}$ Sesuai dengan sabda Nabi yang berbunyi :

\footnotetext{
8 Beni Ahmad Saebani, Op Cit, hal 115.
}

$$
\begin{aligned}
& \text { عن عمرو بن شعيب عن ابيه عن جلده قال قال رسول الله }
\end{aligned}
$$

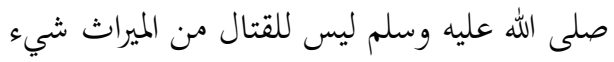

"Dari 'Amr bin Syu'aib dari ayahnya dari kakeknya berkata ia: berkata Rasulullah saw:

"Tidak ada hak bagi pembunuh sedikitpun untuk mewarisi",9

Selain itu, Ibnu Abbas juga meriwayatkan sebuah hadis yang berbunyi:

من قتل قتيلا فإنه لايرثه وان لم يكن له وارث غيره وان كان له

$$
\text { ولده فليس لقاتل ميراث }
$$

"Barang siapa membunuh seorang korban, maka ia tidak dapat mempusakainya walaupun si korban tidak mempunyai ahli waris selainnya dan jika si korban itu bapaknya atau anaknya, maka bagi pembunuh tidak berhak menerima harta peninggalan"

Beberapa hadis tersebut menjelaskan bahwa pembunuhan pewaris menghalangi yang bersangkutan mewarisi harta warisan pewaris yang dibunuh. Kaitannya dengan beberapa hadis di atas adalah kaidah fiqhiyah berikut:

$$
\text { من استعجل الشيء قبل اوانه عوقب بحرمانه }
$$

"Barang siapa ingin mempercepat mendapatkan sesuatu sebelum waktunya maka ia dikenakan sanksi tidak boleh mnedapatkannya" 10

Fuqaha sepakat dalam menetapkan bahwa pembunuhan itu menurut prinsipnya menjadi penghalang mewarisi, namun mereka memperselisihkan macam-macam pembunuhan yang bisa dikategorikan sebagai penghalang mewarisi.

Ulama Hanafiyah menentukan bahwa pembunuhan yang dapat menggugurkan hak waris adalah semua jenis pembunuhan yang wajib membayar kafarat. Adapun ulama Malikiyah berpendapat hanya pembunuhan yang disengaja atau yang direncanakan yang dapat menggugurkan hak waris. Ulama Hanabilah berpendapat bahwa pembunuhan yang dinyatakan sebagai penggugur hak waris adalah setiap jenis pembunuhan yang mengharuskan pelakunya diqishash, membayar diyat, atau membayar kafarat. Sedangkan ulama Syafi'iyah berpendapat bahwa pembunuhan dengan segala cara dan macamnya tetap menjadi penggugur hak

\footnotetext{
Abi Bakar bin Husein bin Ali Al-Baihaki, Sunanul Qubra, juz 6 (Beirut: Dar al-Fikr, t.th), hal 220.

10 H.A. Dzajuli, Kaidah-Kaidah Fikih: Kaidah-Kaidah Hukum Islam dalam Menyelesaikan Masalah-Masalah yang Praktis, (Jakarta: Kencana, 2006), hal 106.
} 
waris. $^{11}$

Pendapat terkuat adalah dari ulama Hanabilah karena pendapat mereka selaras dengan dalildalil yang menegaskan pembunuhan menjadi penghalang mewarisi di samping pendapat tiga mazhab yang lain.

Berbeda dengan ketentuan di atas yang menjelaskan bahwa salah satu penghalang menerima waris karena alasan pembunuhan, Kompilasi Hukum Islam (KHI) yang substansinya mengacu kepada berbagai literature fikih, justru menyatakan bahwa bukan saja pembunuhan yang dapat menjadi penghalang mewarisi, namun juga kepada perbuatan percobaan pembunuhan. ${ }^{12}$

Sejauh ini, kehadiran KHI diharapkan menjadi pedoman dan acuan bagi setiap Pengadilan Agama dalam wilayah hukum Indonesia untuk menyelesaikan perkara-perkara yang diajukan kepadanya, tidak terkecuali dalam masalah kewarisan yang tertuang dalam buku II nya memuat tentang halanagn mewarisi yaitu dalam pasal 173 yang berbunyi: "seorang terhalang menjadi ahli waris apabila dalam putusan hakim yang telah mempunyai kekuatan hukum tetap, dihukum karena: a) dipersalahkan telah membunuh atau mencoba membunuh atau menganiaya berat para pewaris; b) dipersalahkan secara memfitnah telah mengajukan pengaduan bahwa pewaris telah melakukan suatu kejahatan yang diancam dengan hukuman 5 tahun penjara atau hukuman yang lebih berat.

Berdasarkan pasal di atas, tertera jelas bahwa KHI menyatakan bahwa bukan hanya pembunuhan yang mengahalani kewarisan namun juga perbuatan percobaan pembunuhan. Perbuatan percobaan pembunuhan belum mengakibatkan kepada hilangnya nyawa seseorang. Selain itu, penganiyaan berat dan memfitnah pewaris pun juga termasuk dalam halangan mewarisi.

Adapun dalam beberapa literature fikih hanya ada tiga hal yang mengakibatkan seseorang terhalang mewarisi atau gugur haknya sebagai ahli waris yaitu perbedaan agama, perbudakan, dan pembunuhan. Pembunuhan yang dimaksud adalah pembunuhan yang disengaja sedangkan pembunuhan yang tidak disengaja masih menjadi perdebatan yang berujung pada khilafiyah di kalangan fuqaha.

Kewarisan adalah hak seseorang yang telah ada ketetapannya dalam Al Qur'an dan tidak

\footnotetext{
${ }^{11}$ Ibid.

${ }^{12}$ Lihat pasal 173 Kompilasi Hukum Islam
}

dapat dicabut kembali kecuali ada dalil yang kuat. Dicabutnya hak seseorang untuk memperoleh harta warisan karena percobaan pembunuhan ataupun penganiayaan, apalagi memfitnah-meskipun ketiganya adalah tindak kejahatan-tidak serta merta dapat menghilangkan hak seseorang dalam kewarisan.

\section{Pokok Bahasan}

Berdasarkan uraian di atas, tulisan ini ingin mengetahui alasan atau dasar hukum dari perumusan pasal penghalang kewarisan khususnya pasal 173 huruf (a) kemudian akan ditelaah dari sudut pandang hukum Islam.

Penelitian ini bersifat studi kepustakaan (library research) yang sifatnya deskriptif analisis yang berdasarkan pada kajian teks. Metode ini diperlukan untuk menggali data, fakta, serta teori yang membuat suatu kepercayaan itu benar. Pendekatan yang digunakan adalah adalah normative legal research yaitu penelaahan hukum normative dengan memusatkan kajian pada interpretasi teks Kompilasi Hukum Islam khususnya pasal 173 huruf (a).

\section{Penghalang Kewarisan dalam Hukum Waris Islam}

Ulama Hanafiyah menyebutkan ada empat macam penghalang kewarisan yang masyhur yaitu perbudakan, pembunuhan, perbedaan agama, dan perbedaan negara. Al-Quduri menambahkan murtad dalam penghalang kewarisan. ${ }^{13}$ Sementara itu ada juga yang menambahkan ketidaktahuan waktu kematian seperti peristiwa kebakaran atau tenggelam, dikarenakan salah satu syarat kewarisan adalah hidupnya ahlli ketika pewaris meninggal dunia dan waris mewarisi tidak bisa dilaksanakan bila ada keraguan.

Selain itu, ketidaktahuan ahli waris juga dimasukkan dalam kategori penghalang kewarisan yang terdapat dalam beberapa hal diantaranya sebagai berikut: ${ }^{14}$

1. Seorang wanita yang mengasuh bayi orang lain dan juga bayinya sendiri. Wanita tersebut meninggal dunia dan tidak diketahui yang mana anaknya diantara dua bayi tersebut, maka tidak ada yang mewarisi diantara keduanya.

\footnotetext{
${ }^{13}$ Wahbah Zuhaili, Al-Figh Al-Islami wa Adillatubu, juz x, (Dmsyk: Dar al-Fikr, 1997), hal 7710.

${ }^{14}$ Ibid.
} 
2. Seorang yang muslim dan seorang yang kafir menyewa satu orang pengasuh untuk anak mereka sampai mereka dewasa. Tidak diketahui yang mana anak dari si muslim dan yang mana anak si kafir, sedangkan kedua anak tersebut muslim. Maka, kedua anak tersebut tidak bisa mewarisi dari orang tuanya masing-masing

Sebagian ulama Hanafiyah menyebutkan ada sepuluh penghalang kewarisan yaitu perbedaan agama, perbudakan, pembunuhan sengaja, li'an, zina, keraguan dalam menentukan kematian muwarris, kehamilan, keraguan tentang hidupnya seeorang anak, keraguan dalam menentukan kematian yang lebih dulu antara muwarris dan ahli waris, dan keraguan dalam menentukan jenis kelamin laki-laki atau perempuan. ${ }^{15}$

Adapun ulama Syafi'iyah dan Hanabilah menyebutkan hanya ada tiga penghalang kewarisan yaitu perbudakan, perbedaan agama, dan pembunuhan. Namun, ada beberapa ulama Syafi'iyah yang menambahkan tiga lagi penghalang kewarisan yaitu pertama, perbedaan kekafiran antara kafir dzimmi dan kafir harabah (kafir dzimmi dan kafir harabah tidak saling mewarisi karena putusnya tali perwalian antara mereka); kedua, riddab. ${ }^{16}$ Orang yang murtad tidak bisa mewarisi harta orang yang muslim ataupun kafir, harta yang dimilikinya pun tidak bisa diwarisi dan diserahkan kepada baitul mal.

Pada dasarnya, halangan mewarisi yang disepakati oleh fuqaha ada tiga macam yaitu perbudakan, berbeda agama, dan pembunuhan. Perbudakan menjadi halangan mewarisi bukanlah karena status kemanusiannya, tetapi semata-mata karena status formalnya sebagai hamba sahaya (budak). Mayoritas ulama sepakat bahwa seorang budak terhalang untuk menerima warisan karena ia dianggap tidak cakap melakukan perbuatan hukum. ${ }^{17}$

\footnotetext{
${ }^{15}$ Wahbah Zuhaili, Op Cit

${ }^{16}$ Fa'il dari riddah adalah murrtad yaitu orang yang meninggalkan agama Islam dan memeluk agama lain atau tidak beragama sama sekali yang biasanya disebut istilah atheis

${ }^{17}$ Budak dibagi dalam lima macam yaitu (1) budak Qinnan (budak murni), (2) budak muba'ad (setengah budak setengah merdeka), (3) budak mukatab (budak yang berusaha memerdekakan dirinya sendiri dengan kesanggupan untuk membayar angsuran sejumlah uang atau melalui suatu pekerjaan, menurut perjanjian yang telah disepakati antara dirinya dan tuannya), (4) budak
}

Sebagaimana firman Allah dalam surah AnNahl ayat 75 yang dijadikan petunjuk umum dari suatu nash yang sharih yang menafikan kecakapan bertindak seorang hamba sahaya dalam segala bidang yaitu sebagai berikut:

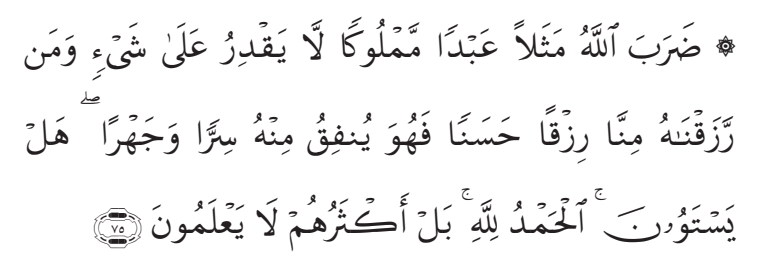

"Allah membuat perumpamaan dengan seorang hamba sahaya yang dimiliki yang tidak dapat bertindak terhadap sesuatupun dan seorang yang kami beri rezki yang baik dari kami, lalu dia menafkahkan sebagian dari rezki itu secara sembunyi dan secara terang-terangan, Adakah mereka itu sama? segala puji Hanya bagi Allah, tetapi kebanyakan mereka tiada mengetahui."

Seorang hamba sahaya atau budak tidak dapat bertindak terhadap sesuatu apapaun karena ia berada di bawah kekuasaan tuannya. Ia tidak cakap mengurusi hak milik kebendaan dengan jalan apa saja. Dalam soal pusaka mempusakai terjadi di satu pihak melepaskan hak milik kebendaan dan di satu pihak yang lain menerima hak milik kebendaan. Oleh karena itu, terhalangnya budak dalam pusaka mempusakai dapat ditinjau dari dua jurusan yaitu mempusakai harta peninggalan dari ahli warisnya dan mempusakakan harta peninggalan kepada ahli warisnya. ${ }^{18}$

Seorang budak tidak mempusakai harta peninggalan ahli warisnya karena pertama, ia dipandang tidak cakap mengurusi harta milik, dan kedua, status kekeluargaannnya terhadap kerabatkerabatnya sudah putus karenanya ia sudah menjadi orang asing bagi keluarganya. ${ }^{19}$ Oleh karena itu, apabila seorang hamba sahaya meninggal dan mempunyai harta peninggalan, maka hartanya itu tidak dapat diwariskan kepda ahli warisnya sendiri karena ia dianggap melarat dan tidak mempunyai harta peninggalan sedikitpun. Pada dasarnya, segala sesuatu yang dimiliki oleh seorang budak adalah milik tuannya sehingga ia tidak mewarisi ataupuan mewariskan apa yang ada padanya.

\footnotetext{
mudabbar (budak yang kebebasannya tergantung kematian tuannya, status kebudakannya kekal selama tuannya masih hidup), (5) ummu al-walad (budak perempuan yang kekal menjadi milik tuannya sampai tuannya meninggal). ${ }^{18}$ Fatchur Rahman, Ilmu Waris, (Bandung: PT. Al-Ma'arif, 1975), hal 84

${ }^{19}$ Ibid.
} 
Secara yuridis, hamba sahaya dipandang tidak cakap melakukan perbuatan hukum karena hak-hak kebendaannya ada pada tuannya sehingga ia tidak bisa menerima bagian warisan dari tuannya. Sebagai "harta" milik tuannya tentu ia tidak bisa memiliki dan dimiliki karena yang memiliki hanyalah yang berstatus merdeka yaitu tuannya. Bahkan, hubungan kekerabatan budak dengan saudaranya atau kerabatnya sendiri terputus karena statusnya sebagai hamba sahaya tersebut. ${ }^{20}$

Penghalang kewarisan kedua adalah perbedaan agama. Berbedanya agama antara muwarris dengan ahli warisnya yang beragama Islam dengan agama lainnya menjadi penghalang dalam kewarisan berdasarkan kesepakatan mazhab hanafi, mazhab Maliki, mazhab Syafi'i, dan mazhab Hambali.

Seorang muslim tidak bisa mewarisi harta dari seorang yang kafir dan sebaliknya walaupun ada hubungan kekerabatan atau perkawinan. ${ }^{21}$ Petunjuk umum terkait hal ini ada pada surah an-Nisa: 141 yang berbunyi:

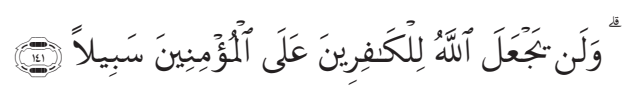

“...dan Allah sekali-kali tidak akan member jalan kepada orang-orang kafir untuk memusnahkan orang-orang yang beriman"

Selain itu, diperkuat pula oleh hadis Nabi yang berbunyi:

عن أسامة ابن زيد قال قال رسول الله صلى الله عليه وسلم

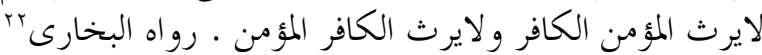

"Dari Usamah ibn Zaid berkata: Rasulullah saw bersabda 'orang Islam tidak mewarisi harta orang kafir dan orang kafir tidak mewarisi harta orang Islam "'. HR. Bukhari.

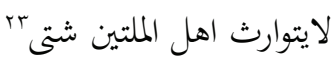

"Tidak dapat saling mewarisi antara dua orang pemeluk agama yang berbeda-beda"

Nabi sendiri mempraktikkan hal tersebut ketika membagikan warisan paman beliau Abu Thalib yang meninggal sebelum masuk Islam. Harta peninggalan Abu Thalib hanya dibagikan kepada

\footnotetext{
${ }^{20}$ Ahmad Rofiq, Fiqh Mawaris, (Jakarta: PT. Raja Grafindo Persada, 2001), hal 39

${ }^{21}$ Wahbah al-Zuhaili, al-Figh al-Islam wa Adillatubu, juz x (Dmsyk: Dar al-Fikr, 1997), hal 7719

22 Abi Abdillah Muhammad Ibn Ismail Ibn Ibrahim alBukhari, Shahih Bukhari, juz IV (Beirut: Dar al-Shab, t.th)

${ }^{23}$ Abu Dawud Sulaiman al-Asy'as al-Sajistani, Sunan Abi Dawnd, (Beirut: Dar al-Ma'rifah, t.th),
}

anak-anaknya yang kafir yaitu 'Uqail dan Thalib, sedangkan anak-anaknya yang sudah masuk Islam tidak diberi bagian oleh Nabi. ${ }^{24}$

Penghalang kewarisan ketiga adalah pembunuhan. Jumhur ulama sepakat bahwa ahlli waris yang membunuh muwarrisnya menjadi terhalang menerima warisan karena haknya sebagai ahli waris telah gugur disebabkan perbuatan pembunuhan tersebut. Pembunuhan terhadap calon muwarri ${ }^{25}$ nya adalah perbuatan yang memutuskan tali silaturrahmi di antara mereka sebagai kerabat. Hubungan kekerabatan adalah salah satu penyebab terjadinya hubungan waris mewarisi diantara muwarris dan ahli warisnya. ${ }^{26}$

Pembunuhan adalah suatu tindak pidana kejahatan yang di dalam istilah agama disebut dengan maksiat, sedangkan hak kewarisan merupakan nikmat, maka dengan sendirinya maksiat tidak boleh dipergunakan sebagai suatu jalan untuk mendapatkan nikmat. ${ }^{27}$ Membunuh muwarrisnya disinyalir ada indikasi untuk mempercepat terjadinya proses kewarisan. Pembunuhan sebagai halangan mewarisi adalah salah satu cara untuk mencegah seseorang yang ingin mempercepat proses pembagian warisan dengan cara tersebut.

Jumhur ulama sepakat pembunuhan merupakan salah satu penghalang kewarisan, namun terdapat perbedaan pendapat mengenai jenis dan macam yang menjadi penghalang tersebut. Ulama mazhab Hanafiyah menyatakan bahwa jenis pembunuhan yang menjadi halangan mewarisi adalah 1) pembunuhan yang dapat diberlakukan qishas yaitu pembunuhan sengaja , direncanakan, dan menggunakan alat yang dapat menghilangkan nyawa orang lain; 2) pembunuhan yang hukumannya berupa kafarat yaitu pembunuhan mirip sengaja seperti seseorang sengaja memukul atau menganiaya orang lain tanpa disertai niat dan tujuan membunuh; 3) pembunuhan kbilaf yang terdiri dari dua macam yaitu khilaf maksud seperti seseorang menembakkan peluru kepada sasaran yang dikira binatang dan mengenai sasaran yang ternyata adalah manusia, lalu meninggal. Kbilaf kedua adalah kbilaf tindakan seperti seseorang menebang pohon yang tiba-tiba pohon tersebut

\footnotetext{
${ }^{24}$ Ahmad Rofiq, Op. Cit, hal 36.

${ }^{25}$ Orang yang mewariskan harta.

${ }^{26}$ Suhrawardi K. Lubis \& Komis Simanjuntak, Hukum Waris Islam (Lengkap dan Praktis), (Jakarta: Sinar Grafika, 1999), hal 55-56.

${ }^{27}$ Ibid.
} 
roboh dan menimpa keluarganya.

Abd al-Qadir Audah dalam buku alTasyri' al-Jina'i al-Islamy memberi contoh, seseorang melepaskan tembakan pada suatu sasaran dengan maksud latihan, tetapi ternyata mengenai keluarganya. Kekeliruan ini terletak pada tindakannya yaitu tidak menggenai sasaran yang dimaksud dan justru mengenai sasaran lain yang berakibat keluarganya meninggal dunia. ${ }^{28}$ Jenis pembunuhan selanjutnya, 4) pembunuhan dianggap khilaf seperti seseorang membawa barang bawaan yang berat, tanpa disengaja bawaan tersebut jatuh dan menimpa saudaranya hingga tewas.

Lebih lanjut ulama Hanafiyah mengatakan bahwa pembunuhan tidak langsung tidak menjadi penghalang kewarisan seperti seseorang menggali lubang di tengah jalan yang bukan miliknya sendiri dan belum mendapat izin dari pemerintah. Kemudian ada keluarganya yang terperosok ke lubang tersebut dan meninggal. Selain pembunuhan tidak langsung, pembunuhan karena hak juga tidak menjadi penghalang mewarisi seperti seseorang yang melakukan qishas atau untuk membela diri, kehormatan, ataupun harta milik. Sebab, larangan mempusakai itu adalah sanksi bagi pembunuhan yang diharamkan sedangkan pembunuhan karena hak bukan termasuk pembunuhan yang diharamkan oleh syara'. ${ }^{29}$ Sebagaimana firman Allah SWT dalam surah Al-Isra: 33 sebagai berikut:

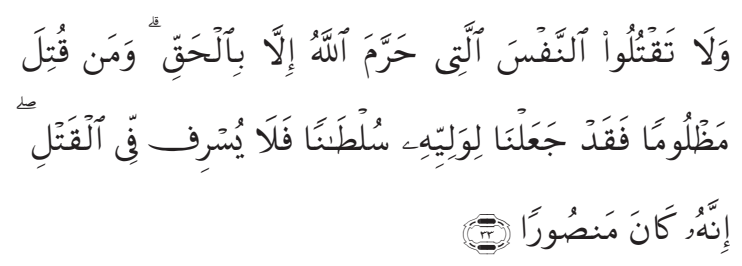

"Dan janganlah kamu membunuh jiwa yang diharamkan Allah (membunuhnya), melainkan dengan suatu (alasan) yang benar. dan barangsiapa dibunuh secara zalim, Maka Sesungguhnya kami Telah memberi kekuasaan kepada ahli warisnya, tetapi janganlah ahli waris itu melampaui batas dalam membunuh. Sesungguhnya ia adalah orang yang mendapat pertolongan."

Selain itu, pembunuhan yang tidak dianggap sebagai penghalang kewarisan adalah pembunuhan yang dilakukan oleh orang yang tidak cakap hukum dan pembunuhan karena 'uzur seperti membunuh

\footnotetext{
28 'Abd al-Qadir 'Audah, al-Tasyri' al-jina'i al-Islamy, juz I, (Mesir: Dar al-Fikr al-'Araby, t.th), hal 84.

${ }^{29}$ Dibenarkan oleh syara' seperti qishas membunuh orang murtad, rajam, dan sebagainya.
}

yang berlebih-lebihan untuk membela diri.

Adapun ulama Malikiyah menyatakan bahwa pembunuhan yang menjadi penghalang kewarisan adalah pembunuhan sengaja, mirip sengaja, dan tidak langsung yang disengaja. Sedangkan pembunuhan yang tidak menjadi penghalang kewarisan adalah pembunuhan karena khilaf, pembunuhan yang dilakukan oleh orang yang tidak cakap melakukan perbuatan hukum, pembunuhan yang dilakukan karena hak atau tugas, dan pembunuhan karena 'uæur uuntuk membela diri. ${ }^{30}$

Ulama mazhab Syafi'iyah menyatakan bahwa semua jenis pembunuhan merupakan penghalang mewarisi yang berlaku secara mutlak. Mereka tidak membedakan jenis pembunuhan, apakah yang dilakukan secara langsung maupun tidak langsung, beralasan atau tidak beralasan. ${ }^{31}$

Dasar hukum yang digunakan adalah petunjuk umum sabda Rasulullah SAW riwayat al-Nasa'i seperti dikutip terdahulu. Selain itu, diperkuat lagi bahwa tindakan pembunuhan dengan segala macam tipenya itu memutuskan tali perwalian/hubungan kekerabatan. Hubungan kekerabatan adalah salah satu penyebab adanya kewarisan.

Sedangkan ulama Hanabilah mengemukakan pendapat yang lebih realistis yaitu bahwa pembunuhan yang menjadi penghalang kewarisan adalah pembunuhan yang diancam dengan hukuman qishas, kafarat, dan diyat yaitu pembunuhan sengaja, mirip sengaja, dianggap khilaf, khilaf, tidak langsung, dan pembunuhan oleh orang yang tidak cakap hukum. ${ }^{32}$

Terdapat tiga macam unsur pembunuhan sengaja, yaitu 1) korban yang dibunuh adalah manusia yang masih dalam keadaan hidup termasuk manusia yang dalam keadaan sekarat (sakit keras); 2) kematian korban adalah hasil dari perbuatan pelaku artinya kematian yang terjadi merupakan akibat dari perbuatan pelaku, jika hubungan sebab akibat tersebut terputus (kematian disebabkan oleh keadaan lain) maka pelaku tidak dianggap sebagai pembunuhan sengaja; dan 3) pelaku tersebut menghendaki terjadinya kematian. ${ }^{33}$ Artinya, pembunuhan dianggap

${ }^{30}$ Ahmad Rofiq, Op. Cit, hal 31-33.

${ }^{31}$ Muhammad Jawad Mugniyah, Al-Akbwalusy Syakbshiyyah 'alaa Madrabibil Khamsah (bab Mirats) diterjemahkan oleh Sarmin Syukur dan Luluk Radliyah, (Surabaya: Al-Ikhlas, 1988), hal 25.

${ }^{32}$ Ahmad Rofiq, Op. Cit, hal 34.

${ }^{33}$ Lihat A. Dzajuli, Fikib Jinayat, ( Jakarta: Raja Grafindo Persada, 1996), hal 128. 
sebagai pembunuhan sengaja jika dalam diri pelaku terdapat niat untuk menghilangkan nyawa korban. Niat untuk menghilangkan nyawa orang lain ini yang membedakan pembunuhan sengaja dengan pembunuhan menyerupai sengaja.

Pendapat tersebut dikemukakan oleh jumhur fuqaha yang terdiri dari Imam Abu Hanifah, Imam Syafi'i, dan Imam Ahmad bin Hambal. Adapun Imam Malik tidak menyaratkan adanya syarat khusus dalam perbuatan pembunuhan ataupun terkait peralatan yang dipakai untuk melakukannya. Dalam pembunhan sengaja yang penting adalah apakah perbuatannya itu sengaja atau tidak. Apabila pelaku sengaja melakukan pemukulan misalnya, meskipun tidak ada maksud untuk membunuh korban maka perbuatannya itu sudah termasuk pembunuhan sengaja. ${ }^{34}$

\section{Penghalang Kewarisan dalam Kompilasi Hukum Islam}

Dalam perjalanan perkembangan hukum Islam di Indonesia, Kompilasi Hukum Islam (KHI) lahir setelah eksistensi Peradilan agama diakui dengan hadirnya UU No. 7 Tahun 1989 tentang Peradilan Agama. KHI adalah kitab himpunan atau rangkaian kitab fikih serta bahan-bahan lainnya yang merupakan hukum materiil PA dalam menyelesaikan masalah perkawinan, kewarisan, dan perwakafan.

Tema utama penyusunan KHI ialah mempositifkan hukum Islam di Indonesia yang dijadikan pedoman oleh para hakim dalam melaksanakan tugasnya sehingga terjamin adanya kesatuan dan kepastian hukum. Sebab untuk dapat berlakunya hukum Islam di Indonesia, harus ada antara lain hukum yang jelas dan dapat dilaksanakan oleh aparat penegak hukum dan masyarakat. Dengan lahirnya KHI semua hakim di lingkungan Peradilan Agama diarahkan kepada persepsi penegakan hukum yang sama. ${ }^{35}$

Kompilasi Hukum Islam terdiri atas 3 buku yaitu buku I tentang perkawinan, buku II tentang kewarisan, dan buku III tentang perwakafan. Masing-masing buku terdiri dari beberapa bab yang dirinci lagi dalam beberapa pasal. KHI memiliki 229

\footnotetext{
${ }^{34}$ Abdul Qadir Audah, Al-Tasyri' al-Jina'iy al-Islamiy: Muqaaranan bi al-Qanun al-Wadh'iy, juz I, (Beirut: ArRisalah Publishing House, 1997), hal 26-27.

${ }^{55}$ M. Yahya Harahap, Informasi Materi Hukum Islam: Mempositifkan Abstraksi Hukum Islam , Jakarta: Logos Wavana Ilmu, 1999) hal 31-32.
}

pasal dengan distribusi yangn berbeda-beda untuk masing-masing buku. Buku I tentang perkawinan memuat 170 pasal, buku II tentang kewarisan memuat 44 pasal, dan buku III tentang perwakafan memuat 15 pasal.

Buku II KHI tentang kewarisan tergolong cukup singkat dibandingkan buku II tentang perkawinan karena hanya terdiri atas 44 pasal. Namun, terlepas dari itu, dalam buku II ini juga cukup banyak menawarkan terobosan-terobosan baru terkait hukum kewarisan untuk mengimbangi kemajuan zaman dengan segala kecanggihan teknologinya. Dalam bab II tentang ahli waris, pasal 173 huruf a dan b berbicara tentang penghalang kewarisan yang berbunyi:

Seorang terhalang menjadi ahli waris apabila dengan putusan hakim yang telah mempunyai hukum tetap, dihukum karena:

a. Dipersalahkan telah membunuh atau mencoba membunuh atau menganiaya berat pada pewaris;

b. Dipersalahkan secara memfitnah telah mengajukan pengaduan bahwa pewaris telah melakukan suatu kejahatan yang diancam dengan hukuman 5 tahun penjara atau hukuman yang lebih berat.

Dalam huruf a diatur tentang terhalangnya seseorang untuk menjadi ahli waris yang pada dasarnya berupa kejahatan terhadap pewaris yaitu membunuh, mencoba membunuh, dan menganiaya berat. Adapun halangan lainnya seperti yang sudah disepakati fuqaha yaitu perbedaan agama tidak dikemukakan secara jelas dalam pasal ini. Namun, KHI hanya menegaskan indikator untuk mengatakan bahwa seseorang itu harus beragama Islam ${ }^{36}$ sebagaimana dalam pasal 172 berikut ini:

"Ahli waris dipandang beragama Islam apabila diketahui dari Kartu Identitas atau pengakuan atau amalan atau kesaksian, sedangkan bagi bayi yang baru lahir atau anak yang belum dewasa beragama menurut ayahnya atau lingkungannya"

1. Tinjauan Normatif

Percobaan pembunuhan dan penganiayaan berat sebagai bentuk tindak pidana tampaknya baik dalam al-Qur'an maupun as-Sunnah tidak memberi pengaturan secara tegas bahwa tindakan tersebut dapat menghalangi seseorang ahli waris untuk mendapatkan warisan. Percobaan pembunuhan

\footnotetext{
${ }^{36} \mathrm{H}$. Abdurrahman, Kompilasi Hukum Islam di Indonesia, (Jakarta: Akademika Pressindo, 2010) hal 78.
} 
dan penganiayaan berat kepada pewaris sebagai penghalang kewarisan merupakan hal baru yang tidak ditemukan dalam dua sumber hukum tersebut.

Sebagaimana dalam uraian terdahulu dijelaskan bahwa walaupun fuqaha masih berselisih pendapat mengenai jenis pembunuhan yang menjadi penghalang kewarisan namun pada dasarnya mereka bersepakat bahwa pembunuhan adalah perbuatan yang menghalangi seseorang untuk mendapat haknya sebagai ahli waris dari pewaris yang menjadi korbannya.

Pada masa lahirnya pendapat para fuqaha tersebut, belum ditemukan usaha atau cara untuk memberikan pertolongan kepada korban yang sedang sekarat akibat perbuatan seseorang yang ingin membunuhnya. Sehingga bisa dipahami mengapa perdebatan fuqaha pada masa itu hanya seputar jenis atau macam dari pembunuhan yang bisa menjadi penghalang kewarisan.

Akibat pesatnya perkembangan teknologi, alat-alat canggih yang menunjang ilmu kedokteran mulai bermunculan dan hal tersebut mempunyai pengaruh yang sangat signifikan dalam tindakan penyelematan korban dan memberikan peluang besar untuk kesembuhan korban.

Berdasarkan kenyataan itulah muncul istilah percobaan pembunuhan. Istilah ini muncul karena perbuatan yang sudah direncanakan sejak awal oleh pelaku, gagal akibat suatu hal yang menyebabkan niatnya untuk membunuh tidak terlaksana dengan sempurna. Usaha percobaan berarti suatu perbuatan yang menjadi bagian dari serangkaian perbuatan yang apabila tidak terganggu akan dapat berakibat dilakukannya kejahatan yang lebih besar. ${ }^{37}$

Para ulama tidak banyak berbicara tentang percobaan melakukan tindak karena perbuatan ini termasuk jarimah ta'zir yang banyak berubah sesuai ruang dan waktu, kebiasaan, serta karakter suatu masyarakat. ${ }^{38}$ Selain itu, dengan adanya aturan-aturan khusus untuk percobaan tidak perlu diadakan, sebab hukuman ta' 2 ir dijatuhkan atas setiap perbuatan maksiat yang tidak dikenakan hukuman had atau kifarat. Karena hukuman had dan kifarat hanya dikenakan atas jarimah-jarimah tertentu yang benar-benar telah selesai, maka artinya

\footnotetext{
${ }^{37}$ Soedjono Dirdjosisworo, Filsafat Peradilan Pidana dan Perbandingan Hukum, (Bandung: CV. Armico, 1984), hal 70.

${ }^{38}$ H. A. Djadzuli, Fikih Jinayat: Upaya Menanggulangi Kejahatan dalam Islam, (Jakarta: PT. Raja Grafindo Persada, 1997), hal 21.
}

setiap percobaan (memulai) sesuatu perbuatan yang dilarang hanya dijatuhi hukuman $t a^{\prime} z^{2}$ ir dan percobaan itu sendiri dianggap maksiat yakni jarimah yang telah selesai juga, meskipun merupakan satu bagian saja di antara bagian-bagian lain yang membentuk jarimah yang tidak selesai, selama satu bagian itu sendiri dilarang. ${ }^{39}$

Masalah percobaan melakukan jarimah ada diperbincangkan dalam fase-fase pelaksanaan jarimah. Seseorang yang melakukan jarimah setidaknya melewati tiga fase yaitu fase pemikiran dan perencanaan, fase persiapan, dan fase pelaksanaan. Percobaan jarimah terletak pada fase pelaksanaan karena dalam fase ini seorang pelaku telah dapat dikenai sanksi bila perbuatannya itu merupakan suatu maksiat meskipun belum selesai. ${ }^{40}$ Jadi, yang dimaksud dengan percobaan di sini adalah mencakup dari ketiga fase tersebut dimana pelaku berpikir, bersiap-siap, kemudian melaksanakan perbuatan namun perbuatan tersebt belum selesai sehingga hasil akhirnya tidak sebagaimana yang diharapkan.

Menurut Asywadie Syukur, hukum Islam menganggap percobaan dalam kejahatan pembunuhan termasuk kejahatan yang sempurna, tanpa melihat kepada akibat dari perbuatan tersebut. ${ }^{41}$

Adapun dalam hukum pidana positif, perbuatan pidana yang tidak selesai dikenal dengan istilah "percobaan". Kitab Undang-Undang Hukum Pidana (KUHP) tidak memberikan rumusan pengertian tentang istilah "percobaan". Namun, N.E. Algra, percobaan adalah berusaha keras menyelesaikan perbuatan yang dapat dipidana, dimana pelakunya tidak dapat menyelesaikan perbuatan itu karena hal di luar kehendaknya sendiri. Menurutnya, kesengajaan pelaku harus nyata dengan adanya permulaan perbuatan kejahatan oleh perbuatan penyelenggaraan. ${ }^{42}$

Bab IV Pasal 53 KUHP $^{43}$ menjelaskan bahwa

\footnotetext{
${ }^{39}$ Makhrus Munajat, Hukum Pidana Islam di Indonesia, (Jogjakarta: TERAS, 2009), hal 42-43.

${ }^{40}$ Ibid

${ }^{41}$ H.M. Asywadie Syukur Lc, Studi Perbandingan Tentang Beberapa Macam Kejahatan dalam KUHP dan Fikih Islam, (Banjarmasin: Lambung Mangkurat University Press, 1990), hal 62.

42 Arvan Sakidjo \& Bambang Poernomo, Hukum Pidana: Dasar Aturan Umum Hukum Pidana Kodifikasi, Jakarta: Ghalia Indonesia, 1990), hal 118.

43 (1) mencoba melakukan kejahatan dipidana, jika niat itu telah ternyata dari adanya permulaan pelaksanaan
} 
percobaan pembunuhan baru dapat dihukum apabila telah memenuhi tiga syarat berikut: 1) adanya niat untuk membunuh; 2) pelaku sudah memulai melakukan perbuatannya; dan 3) perbuatannya gagal karrena terhalang oleh sesuatu yang timbul di luar dari kemauan pelaku. ${ }^{44}$ Pengertian niat dalam pasal tersebut pada umumnya tidak mempunyai arti lain daripada kesengajaan.

Namun, Moeljatno seperti yang dikutip oleh Arvan Sakidjo dan Bambang Poernomo, berpandangan bahwa niat tidak bisa disamakan dengan kesengajaan, tetapi niat bisa berubah menjadi kesengajaan apabila sudah ditunaikan menjadi perbuatan yang dituju. Jadi, makna niat dalam delik percobaan mempunyai arti bahwa dalam hal percobaan selesai arti niat adalah sama dengan kesengajaan dan dalam hal percobaan tertunda arti niat hanya merupakan unsur sifat melawan hukum yang subyektif. ${ }^{45}$

Syarat berikutnya ialah perbuatan pembunuhan itu sudah dimulai dilakukan. Artinya, ia sudah melakukan perbuatan pelaksanaan, tetapi kalau belum dimulai atau baru melakukan persiapan, tidak dapat dihukum. Namun, bagi ahli hukum yang menganut teori percobaan objektif, perbuatan tersebut dapat dihukum jika objeknya sempurna, karena jika objeknya belum sempurna maka sama sekali tidak dapat dihukum. Niat jahat belum cukup untuk dihukum, kecuali sudah ada bahaya yang akan menima objek.

Selain pembunuhan dan percobaan pembunuhan, huruf a pasal 173 KHI juga memasukkan penganiayaan berat terhadap pewaris dijadikan penghalang kewarisan. Hukum Islam membagi penganiayaan menjadi penganiayaan yang menyebabkan kematian (diistilahkan oleh fuqaha sebagai pembunuhah semi sengaja) dan penganiayaan terhadap tubuh yaitu penganiyaan terhadap tubuh manusia yang tidak sampai membawa kepada kematian.

Seperti halnya percobaan pembunuhan, penganiayan berat juga tindakan kejahatan yang

dan tidak selesainya pelaksanaan itu, bukan semata-mata disebabkan karena kehendaknya sendiri; (2) maksimum pidana pokok terhadap kejahatan, dalam hal percobaan dapat dikurangi sepertiga; (3) jika kejahatan diancam dengan pidana mati dan pidana penjara seumur hidup, dijatuhkan pidana penjara paling lama lima belas tahun; (4) pidana tambahan bagi percobaan adalah sama dengan kejahatan selesai.

${ }^{44}$ Aswadie Syukur, Op. Cit, hal 7.

${ }^{45}$ Arvan Sakidjo \& Bambang Poernomo, Op. Cit sengaja dilakukan namun tidak berakhir dengan kematian korban. Penganiayaan berat atau penganiayaan terhadap tubuh manusia dibagi menjadi lima macam bentuk penganiayaan, yaitu: 1) ibanat al-athraf, yaitu memotong anggota badan; 2) idz̧ hab ma'al athraf, yaitu menghilangkan fungsi anggota badan; 3) as-syaj, yaitu pelukaan terhadap kepala dan muka; 4) al-jarh, yaitu pelukaan terhadap selain wajah dan kepala; dan 5) pelukaan yang tidak masuk ke dalam salah satu dari empat macam sebelumnya tersebut. ${ }^{46}$

Adapun dalam hukum pidana positif, penganiayaan diartikan sebagai suatu perbuatan yang menyebabkan perasaan tidak enak, rasa sakit, rusak kesehatan, atau luka. Penganiayaan dibagi dalam dua macam yaitu penganiyaan ringan dan penganiyaan berat. Dikatakan penganiyaan apabila dilakukan dengan sengaja, tidak dengan itikad baik atau melampaui batas. ${ }^{47}$

Dalam pasal 352 dijelaskan bahwa penganiyaan yang tidak menimbulkan penyakit atau halangan untuk menjalankan pekerjaan atau jabatan atau pencarian disebut dengan penganiyaan ringan. Sedangkan penganiyaan berat adalah penganiyaan yang menyebabkan korban luka berat. ${ }^{48}$

KHI tidak memberikan penjelasan yang konkrit tentang apa yang dimaksud dengan percobaan pembunuhan dan penganiyaan berat. Namun, jika redaksi pasal penghalang kewarisan ditelaah dengan seksama yaitu "seorang terhalang menjadi ahli waris apabila dengan putusan hakim yang telah mempunyai hukum yang tetap..." maka disimpulkan bahwa percobaan pembunuhan dan penganiyaan berat yang dimaksud adalah sebagaimana dalam hukum pidana yang berlaku di Indonesia.

Baik percobaan pembunuhan ataupun penganiyaan berat adalah suatu tindak pidana yang melanggar hukum. Oleh karena itu, dalam pasal 173, KHI menegaskan bahwa seseorang yang melakukan perbuatan tersebut kehilangan haknya sebagai ahli waris dari pewaris yang adalah korbannya jika ia telah terbukti bersalah dan putusan hakim pun harus berkekuatan hukum tetap (in kracht).

Di samping itu, karena ada banyak cara yang bisa dilakukan oleh pelaku untuk merealisasikan niatnya misalnya menyewa pembunuh bayaran, maka penetapan pelaku atas perbuatan tersebut

\footnotetext{
${ }^{46}$ Topo Santoso, Op Cit, hal 85

${ }^{47}$ Arvan Sakidjo \& Bambang Poernomo, Op Cit.

${ }^{48}$ Moeljatno, Op. Cit. hal 126.
} 
perlu keputusan hakim. Oleh karena itu, percobaan pembunuhan dan penganiyaan berat ini baru bisa dijadikan alasan penghalang kewarisan apabila telah melalui proses persidangan untuk mengetahui apakah perbuatannya tersebut sudah memenuhi unsur-unsur dari tindak pidana. Lebih dari itu juga untuk membuktikan bahwa pelaku terbukti mempunyai itikad atau motif untuk melakukan perbuatan tersebut atau tidak.

Di Indonesia, perkara pidana termasuk dalam wewenang Pengadilan Negeri yang mengacu kepada KUHP warisan kolonial. Oleh karena itu, melihat pasal 173 yang menyaratkan “... dengan putusan hakim..." maka pengertian percobaan pembunuhan dan penganiyaan berat yang dimaksud mengacu pada KUHP. Sebelum KHI mengakomodir percobaan pembunuhan dan penganiyaan berat sebagai penghalang kewarisan, jauh sebelumnya Kitab Undang-Undang Hukum Perdata (Burgerlijk Wetbook/BW) telah lebih dulu mengeluarkan satu pasal yang memuat tentang ketentuan itu yaitu pada buku II tentang kebendaan pasal 838 yang berbunyi:

"yang dianggap tak patut menjadi waris dan karenanya pun dikecualikan dari pewarisan ialah:

1. Mereka yang telah dihukum karena dipersalahkan telah membunuh atau mencoba membunuh si yang meninggal;

2. Mereka yang dengan putusan hakim pernah dipersalahkan karena secara memfitnah telah mengajukan pengaduan terhadap si yang meninggal, ialah suatu pengaduan yang terancam dengan hukuman penjara lima tahun atau hukuman lebih berat;

3. Mereka yang dengan kekerasan atau perbuatan telah mencegah si yang meninggal untuk membuat atau mencabut surat wasiatnya;

4. Mereka yang telah menggelapkan, merusak, atau memalsukan surat wasiat si yang meninggal ${ }^{49}$

Proses penyusunan KHI memiliki pedoman yang telah ditetapkan dan tidak boleh dilampaui yaitu berpegang pada sumber hukum utama (Al-Qur'an dan As-Sunnah) namun tidak menutup langkah yang mengacu kepada pemikiran dan pengkajian seperti merumuskan hal yang tidak terdapat dalam nash dan mengutamakan pemecahan masalah masa kini

\footnotetext{
${ }^{49}$ R. Subekti \& R. Tjitrosudibio, Kitab Undang-Undang Hukum Perdata, (Jakarta: PT. Pradnya Paramita, 2007), hal 223
}

melalui ijtihad. KHI mengakomodir permasalahan baru yang muncul dengan merumuskan beberapa pasalnya terkait hal tersebut.

Dalam Islam, ijtihad menempati posisi yang sangat penting. Terbukti dari banyaknya ayat-ayat Al-Qur'an dan hadis Nabi yang menyinggung tentang ijtihad. Islam bukan saja memberi legalitas pada ijtihad, akan tetapi ia juga mentolerir adanya perbedaan pendapat sebagai konsekuensinya. Ijtihad sendiri merupakan sarana untuk menyelesaikan berbagai problematika kehidupan baru yang tidak dijelaskan ketentuan hukumnya dalam Al-Qur'an dan Hadis Nabi. Dalam catatan sejarah yang panjang, melalui instrument ijtihad inilah doktrindoktrin Islam bisa berkembang secara dinamis dan mencapai kejayaannya. ${ }^{50}$

Secara umum, para pencetus tema-tema pemikiran hukum di Indonesia meyakini bahwa ijtihad merupakan perwujudan kegiatan berpikir yang inheren dengan inti ajaran Islam itu sendiri (Al-Qur'an maupun hadis). Ijtihad lahir atas dorongan Al-Qur'an dan hadis agar manusia mempergunakan pikirannya dalam menghadapi berbagai problem kehidupan. Penggunaan ijtihad menurut mereka dibutuhkan untuk memecahkan persoalan-persoalan yang muncul dan melakukan terobosan-terobosan hukum sebagai langkah reaktualisasi dan pengembangan hukum Islam dalam era modernisasi dan globalisasi. ${ }^{51}$

Sebagai respon terhadap era tersebut dimana umat Islam dihadapkan pada persoalan kontemporer yang belum pernah dibahas oleh ulama terdahulu, maka untuk menjawabnya memerlukan sarana ijtihad agar Islam benar-benar shalibun li kulli zaman wa makan. Seperti yang dikemukakan oleh Fathurrahman Djalil bahwa untuk hukum yang lebih rinci, syari'at Islam hanya menetapkan kaidah dan membrikan patokan umum. Maka, untuk pengembangan hukum tersebut perlu ijtihad yang tetap bersumber pada Al-Qur'an dan hadis nabi. ${ }^{52}$

Salah satu metode yang bisa diterapkan terkait percobaan pembunuhan dan penganiyaan berat ditetapkan sebagai penghalang kewarisan oleh $\mathrm{KHI}$ adalah metode qiyas. Metode ini mempunyai empat unsur yang harus dipenuhi yaitu ashal, hukum ashal,

\footnotetext{
${ }^{50}$ Lihat Mahsun Fuad, Hukum Islam Indonesia: Dari nalar Parsipatoris Hingga Emansipatoris, (Yogyakarta: PT. LKis Pelangi Aksara, 2005), hal 188

${ }^{51}$ Ibid

52 Fathurrahman Djamil, Filsafat Hukum Islam, Jakarta: Logos Wacana Ilmu, 1997), hal 30.
} 
furu', dan illat hukum. Pembunuhan yang dijadikan penghalang kewarisan adalah sebagai ashal, hukum ashalnya adalah terhalang mewarisi, dan percobaan pembunuhan sebagai furu'.

Seseorang yang dipersalahkan telah melakukan percobaan pembunuhan berarti unsur-unsur percobaan tersebut sudah terpenuhi sebagaimana disyaratkan dalam KUHP. Unsur-unsur tersebut yaitu telah ada niat/maksud untuk berbuat, perbuatan tersebut sudah mulai dilaksanakan, perbuatannya gagal karena terhalang oleh sesuatu yang muncul di luar kehendaknya. ${ }^{53}$

Dilihat dari adanya unsur niat tersebut, maka terlihat jelas bahwa pelaku memang berkeinginan untuk membunuh namun hasil akhir dari perbuatan tersebut tidak sesuai keinginan. Dalam Islam niat sangat berperan penting untuk membedakan jenis perbuatan yang satu dengan yang lainnya.

Berdasarkan pengertian percobaan pembunuhan itu sendiri, maka niatnya adalah bukan sekedar untuk coba-coba tetapi benarbenar ingin menghilangkan nyawa seseorang. Niat ini sama dengan niat yang ada dalam pembunuhan sehingga dapat disimpulkan bahwa pembunuhan dan percobaan pembunuhan memiliki kesamaan niat. Persamaan lainnya adalah alat yang digunakan adalah alat mematikan. Baik pembunuhan maupun percobaan pembunuhan sama-sama menggunakan alat mematikan yang diyakini pelaku pada dasarnya dapat menghilangkan nyawa orang lain. Selain itu, apabila seseorang dinyatakan telah melakukan pembunuhan, berarti perbuatan tersebut sudah terlaksana hingga mengakibatkan kematian korbannya. Sedangkan dalam percobaan pembunuhan, pelaku juga sudah mulai melaksanakan niatnya, namun hasilnya tidak sesuai rencana.

Oleh karena itu, pembunuhan dan percobaan pembunuhan memiliki kesamaan dari aspek niat, alat yang digunakan, dan sudah terlaksananya niat tersebut. Perbedaan keduanya hanya terdapat pada hasil akhir. Namun, jika menelisik lebih jauh bahwa gagalnya hasil akhir yang diinginkan tersebut bukan atas kehendak si pelaku maka pada dasarnya percobaan pembunuhan juga termasuk pembunuhan.

Adapun penganiyaan berat yang menitikberatkan pada anggota tubuh dapat menyebabkan penderitaan yang berkepanjangan bagi korban. Bahkan seseorang yang dianiaya berat ${ }^{53}$ Moeljatno, Op. Cit, hal 24. ini dapat kehilangan gairah hidup dan mengalami trauma berat yang tidak ubahnya seperti orang mati. Dilihat dari akibat yang diderita, penganiyaan berat lebih sadis daripada pembunuhan.

Berdasarkan uraian tersebut, maka illat yang terdapat pada ashal yaitu pembunuhan sama jenisnya dengan illat yang terdapat dalam furu' dari segi rukun dan syarat qiyas terpenuhi, maka percobaan pembunuhan dan penganiyaan berat bisa dihukumkan sama dengan pembunuhan melalui metode qiyas yaitu qiyas adna atau qiyas yang illat pada cabangnya lebih rendah bobotnya daripada illat yang terdapat pada ashal.

Oleh karena itu, percobaan pembunuhan dan penganiyaan berat dapat dimasukkan dalam penghalang kewarisan sebagaimana pembunuhan. Pada dasarnya, pembunuhan, percobaan pembunuhan, dan penganiyaan berat memutus tali silaturrahmi keluarga.

2. Tinjauan Filosofis

Salah satu prinsip hukum Islam yaitu menjauhi kemudharatan dan mengambil kemashlahatan. Prinsip tersebut bisa tercapai apabila lima unsur yang pokok dapat dipelihara dan diwujudkan yaitu pemeliharaan terhadap agama, jiwa, akal, keturunan, dan harta. Berdasarkan prinsip tersebut, maka ketika percobaan pembunuhan dan penganiyaan berat menjadi penghalang kewarisan oleh KHI dapat dianggap sebagai upaya untuk menjauhi kemudharatan. Memelihara jiwa atau hifzh nafs adalah salah satu aplikasi dari maqashid syariah ddalam rangka mencapai kemashlahatan.

Seseorang yang mencoba membunuh atau menganiaya berat "calon muwarris" nya disinyalir ingin mempercepat pembagian warisan karena pada dasarnya warisan akan diperoleh apabila pemilik harta tersebut meninggal. Jalan/cara untuk mempercepat pembagian warisan tersebut harus ditutup sebagai tindakan preventif. Dalam ranah ushul fikih, tindakan preventif itu disebut metode sadd al-zariah.

Para ulama mengemukakan dua sisi yang dapat dilihat dari zari'at yaitu dari sisi motivasi seseorang dalam melakukan suatu perbuatan dan sisi dampak atau akibat yang ditimbulkan oleh perbuatan tersebut. ${ }^{54}$ Mencoba membunuh dan menganiaya berat "calon muwarris" nya memiliki unsur kesengajaan dan indikasi kuat untuk mempercepat mendapat warisan. Dua perbuatan

${ }^{54}$ Rachmat Syafi'I, Ilmu Ushul Fikih, (Bandung: CV. Pustaka Setia, 2007), hal 136, 
ini memiliki dampak yang tidak kalah hebat dari pembunuhan. Oleh karena itu, orang yang ingin mempercepat warisan dengan dua perbuatan tersebut dapat dicegah jika jalannya tertutup yaitu dengan menutup hak warisnya.

\section{Penutup}

Berdasarkan uraian di atas, maka terdapat beberapa simpulan yaitu sebagai berikut:

1. Kompilasi Hukum Islam sebagai perwujudan hukum Islam yang bercorak keindonesian ini ingin menerapkan konsep maqashid al-syari'ah dengan menitikberatkan pada nilai-nilai berupa kemashlahatan manusia di antaranya adalah menjaga kemashlahatan jiwa. Menghalangi hak waris seseorang karena percobaan pembunuhan dan penganiyaan berat terhadap muwarrisnya, maka jiwa manusia dapat dipelihara karena pada dasarnya Islam sangat menghargai jiwa manusia.

2. Kompilasi Hukum Islam adalah kumpulan hasil ijtihad para ulama Indonesia dalam rangka mencanangkan fikih keindonesian dengan tetap memegang nilai-nilai Islam yang universal. Ada beberapa metode ijtihad yang diterapkan dalam pasal 173 huruf (a) yaitu metode qiyas dan sadd al-zari'at. Dua metode ini secara umum digunakan untuk tindakan preventif terhadap perbuatan mempercepat pembagian warisan dengan melakukan percobaan pembunuhan dan penganiyaan berat kepada muwarrisnya.

\section{Daftar Pustaka}

Abdurrahman, Kompilasi Hukum Islam di Indonesia, Jakarta, Akademika Pressindo, 2010

A. Dzajuli, Kaidah-Kaidah Fikih: Kaidah-Kaidah Hukum Islam dalam Menyelesaikan MasalahMasalah yang Praktis, Jakarta, Kencana, 2006

Al-Baihaki, Abi Bakar bin Husein bin Ali, Sunanul Qubra, juz 6 Beiru, Dar al-Fikr, t.th

Al-Bukhari, Abi Abdillah Muhammad Ibn Ismail Ibn Ibrahim, Shabih Bukhari, juz IV, Beirut, Dar al-Shab, t.th

Al-Sajistani, Abu Dawud Sulaiman al-Asy'as, Sunan Abi Dawnd, Beiru, : Dar al-Ma'rifah, t.th

'Audah, Abd al-Qadir, al-Tasyri' al-jina'i al-Islamy, juz I, Mesir, Dar al-Fikr al-'Araby, t.th

Departemen Agama RI, AL-Qur'an dan Terjemahnya, Jakarta, CV. Naladana, 2004
Dirdjosisworo, Soedjono, Filsafat Peradilan Pidana dan Perbandingan Hukum, Bandung, CV. Armico, 1984

Djamil, Fathurrahman, Filsafat Hukum Islam, Jakarta, Logos Wacana Ilmu, 1997

Fuad, Mahsun, Hukum Islam Indonesia: Dari nalar Parsipatoris Hingga Emansipatoris, Yogyakarta, PT. LKis Pelangi Aksara, 2005

Harahap, M. Yahya, Informasi Materi Hukum Islam: Mempositifken Abstraksi Hukum Islam, , Jakarta, Logos Wavana Ilmu, 1999

K. Lubis, Suhrawardi \& Komis Simanjuntak, Hukum Waris Islam (Lengkap dan Praktis), Jakarta, Sinar Grafika, 1999

Mugniya, Muhammad Jawad , Al-Akhwalusy Syakhshiyyah 'alaa Madrabibil Khamsah (bab Mirats) diterjemahkan oleh Sarmin Syukur dan Luluk Radliyah, Surabaya, Al-Ikhlas, 1988

Munajat, Makhrus, Hukum Pidana Islam di Indonesia, (Jogjakarta: TERAS, 2009

Prodjodikoro, Wirjono, Hukum Waris Indonesia, Bandung, Sumur Bandung, 1991

R. Subekti \& R. Tjitrosudibio, Kitab Undang-Undang Hukum Perdata, Jakarta, PT. Pradnya Paramita, 2007

Rahman, Fatchur, Ilmu Waris, Bandung, PT. AlMa'arif, 1975

Ramulyo, Mohd. Idris, Hukum Kewarisan, Hukum Perkawinan, Hukum Acara Peradilan Agama dan Zakat Menurut Hukum Islam, Jakarta, Sinar Grafika, 1990

Rifa'i, Mohammad, Kifayatul Akhyar, Semarang: Toha Putra, 1978

Rofiq, Ahmad, Fiqh Mawaris, Jakarta, PT. Raja Grafindo Persada, 2001

Saebani, Beni Ahmad, Fikih Mawaris, Bandung, Pustaka Setia, 2000

Sakidjo, Arvan \& Bambang Poernomo, Hukum Pidana: Dasar Aturan Umum Hukum Pidana Kodifikasi, Jakarta, Ghalia Indonesia, 1990

Syafi'I, Rachmat, Ilmu Ushul Fikih, (Bandung: CV. Pustaka Setia, 2007

Syukur,. Asywadie, Studi Perbandingan Tentang Beberapa Macam Kejahatan dalam KUHP dan Fikib Islam, Banjarmasin, Lambung Mangkurat University Press, 1990 
Wahidah, Al-Mafqud: Kajian Tentang Kewarisan Orang Hilang, Banjarmasin, Antasari Press, 2008

Zuhaili, Wahbah, Al-Fiqh Al-Islami wa Adillatubu, juz x, Dmsy, Dar al-Fikr, 1997 